\title{
Post-harvest physiology of pitaya at different ripening stages
}

\section{Fisiologia pós-colheita de pitaya em distintos estádios de maturação}

\author{
Maristella Martineli*; Ariane Castricini²; Victor Martins Maia'; Camila Maida de \\ Albuquerque Maranhão' ${ }^{1}$
}

\section{Highlights}

Pitaya picked commercially immature shows increased respiratory after harvest. Ascorbic acid content is similar between commercially immature and ripe pitaya. Total betacyanin content in pitaya picked commercially immature will not change.

\begin{abstract}
Red-fleshed pitaya is an attractive fruit not due only to the color of its flesh and skin, but also the scaly shape of its skin. In addition to being a source of vitamins and minerals, it has high commercial value and represents an alternative for cultivation in semiarid regions. Information about the post-harvest physiology of pitaya, which interferes with its ripening, allows the adoption of preservation and quality-maintenance practices. This study examines the respiratory activity and post harvest alterations of pitaya picked in the commercially immature stage of ripeness, by comparing them with fruits picked fully ripe. Physical and chemical aspects of the fruits were evaluated in two harvests, in 2019 and 2020. Six days after harvest, there was an increase in respiratory activity and a change in color in both ripe and commercially immature fruits. Therefore, pitayas picked commercially immature in both harvests had an increase in respiratory activity post-harvest, with a change in skin color during storage; and six days after harvest, in the 2019 harvest, the fruits resembled those that ripened on the plant, without having their quality compromised. However, in the 2020 harvest, six days after harvest, the fruits picked fully ripe showed soluble solids/titratable acidity ratio, betacyanins and ascorbic acid contents similar to those measured in the commercially immature fruits.
\end{abstract}

Key words: Fruit quality. Harvest point. Hylocereus polyrhizus. Respiratory activity.

1 Profs. Drs., State University of Montes Claros, UNIMONTES, Janauba Campus, MG, Brazil. E-mail: maristella. martineli@unimontes.br; victor.maia@unimontes.br; camila.maida@unimontes.br

2 Researcher, Dra., Agricultural Research Corporation of Minas Gerais, EPAMIG North, Nova Porteirinha, MG, Brazil. E-mail: ariane@epamig.br

* Author for correspondence

Received: Aug. 12, 2020 - Approved: Oct. 19, 2020 


\section{Resumo}

A pitaya de polpa vermelha é uma fruta atrativa, não somente pela coloração da polpa e casca, mas também pelo formato escamoso da casca. É fonte de vitaminas e minerais, tem alto valor comercial, sendo uma alternativa de cultivo para regiões semiáridas. O conhecimento sobre a fisiologia pós-colheita da pitaya, que interfere na maturação, permite a adoção de práticas de conservação e manutenção da qualidade. Objetivou-se avaliar a atividade respiratória e as modificações pós-colheita de pitaya colhida em estágio de maturação comercialmente imaturas, comparando-as com os frutos colhidos completamente maduros. Em duas safras, 2019 e 2020, foram avaliados os aspectos físicos e químicos dos frutos e verificou-se que seis dias após a colheita ocorre aumento da atividade respiratória e mudança na coloração em frutos em maturação ou comercialmente imaturos. Portanto, pitayas colhidas comercialmente imaturas nas duas safras tiveram aumento da atividade respiratória após a colheita, com mudança na coloração da casca no decorrer do armazenamento, sendo que seis dias após a colheita, na safra 2019, os frutos se assemelharam àqueles amadurecidos na planta, não prejudicando a qualidade. Porém, na safra 2020, seis dias após a colheita, frutos colhidos completamente maduros apresentaram relação sólidos solúveis/acidez titulável, teor de betacianinas e ácido ascórbico semelhantes aos frutos colhidos comercialmente imaturos.

Palavras-chave: Atividade respiratória. Hylocereus polyrhizus. Ponto de colheita. Qualidade dos frutos.

\section{Introduction}

Pitaya (also known as 'dragon fruit') is a plant native to America that belongs to the family Cactaceae (Donadio, 2009). The plant predominantly exhibits the acid metabolism of Crassulaceae, that is, plants whose $\mathrm{CO}_{2}$ fixation mechanism has a different stomatal opening pattern. This metabolism provides the plant with reduced use of water and greater tolerance to drought, as it has the ability to open its stomata at night and close them during the day, significantly reducing excessive water loss to the environment. The $\mathrm{CO}_{2}$ absorbed during the night is converted to malic acid and stored temporarily in vacuoles. Subsequently, in the presence of light, malic acid is decarboxylated and $\mathrm{CO}_{2}$ is used in photosynthetic reactions by the action of ribulose-1,5-bisphosphate carboxylase/oxygenase (Taiz, Zeiger, Møller, \& Murphy, 2015). Thus, despite originating from tropical and subtropical forests in America
(Mizrahi \& Nerd, 1999), its species (e.g. Hylocereus undatus) exhibit good adaptability in semiarid regions (Weiss, Mizrahi, \& Raveh, 2010), which are characterized by low rainfall that is distributed in a few months of the year, in addition to high temperatures. In another study, Tel-Zur et al. (2011) also mentioned that Hylocereus (Berger) Britton et Rose has commercial potential as an exotic fruit tree in arid and semi-arid lands.

According to Chitarra and Chitarra (2005), after harvesting, the main physiological event in fruits is respiration, whose chemical energy released is used to continue the synthesis processes fundamental to ripening (climacteric fruits), such as profound changes in substances such as proteins, glycids, organic acids, mineral vitamins and some specific cell-wall components. Thus, the control of respiration becomes a crucial condition for maintaining quality and extending the useful life of perishable plant products. 
Therefore, studying and knowing the physiology of a fruit is important for understanding the changes in plant metabolism that occur during the stages of growth, harvest, handling in the packing house and storage conditions as well as how these stages influence the quality of the plant (Gómez-Galindo, Herppich, Gekas, \& Sjöholm, 2004). For these authors, distinguishing the physiological state, as well as its changes, is also fundamental, since it directly influences the aforementioned post-harvest operations.

In this respect, regarding the postharvest physiology of fruits, reports in the literature are controversial. One of them, based on the observed low concentration and absence of the ethylene and $\mathrm{CO}_{2}$ peak, describes that pitayas of the species $H$. undatus and $H$. polyrhizus exhibit a non-climacteric behavior (Nerd, Gutman, \& Mizrahi, 1999). The same statement was made by Zee, Yen and Nishina (2004) and Jamaludin, Ding and Hamid (2011). However, it was also reported that the yellow pitaya (Hylocereus megalanthus and
Acanthocereus pitajaya) expresses a behavior that tends to climacteric (Deaquiz, ÁlvarezHerrera, \& Fischer, 2014; Duarte, Rivera, \& Cuenca, 2005).

On these bases, this study was conducted to examine respiratory activity and post-harvest alterations in pitaya $(H$. polyrhizus) picked at different maturity stages.

\section{Material and Methods}

\section{Raw material}

This study involved fruits popularly known as red-fleshed pitaya ( $H$. polyrhizus), which were acquired from a commercial area in the municipality of Janaúba, MG, Brazil, in the 2019 and 2020 harvests (Figure 1). Local geographic coordinates are $43^{\circ} 18^{\prime} 56^{\prime \prime}$ $\mathrm{W}$ and $15^{\circ} 47^{\prime} 4 " \mathrm{~S}$, at an average altitude of approximately $547 \mathrm{~m}$. The typical climate is a Tropical Aw type, characterized by dry winters, according to the Köppen classification.

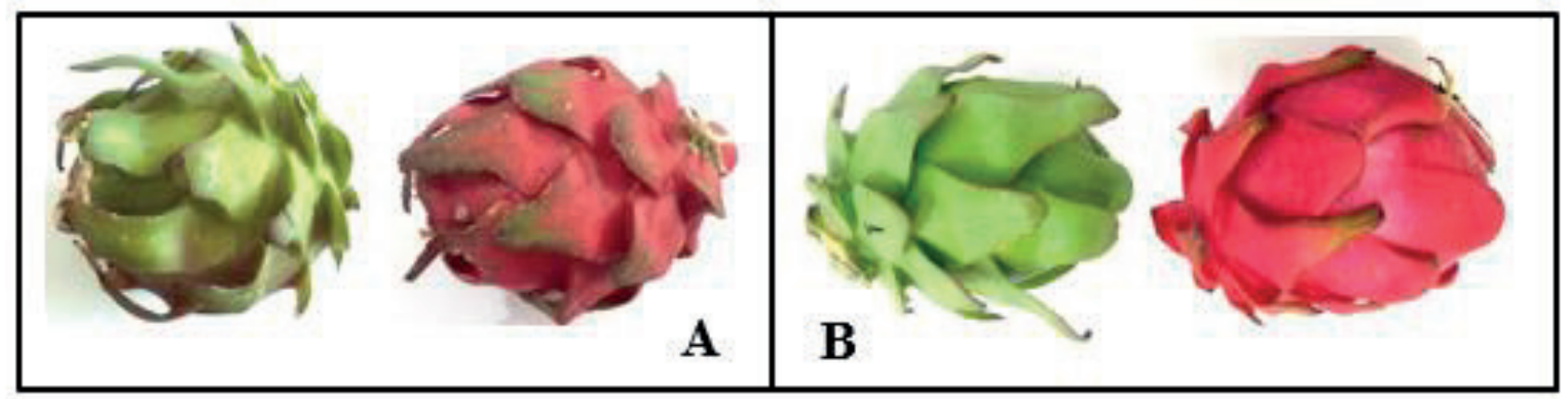

Figure 1. Pitaya (Hylocereus polyrhizus) picked at the commercially immature (right) and ripe (left) stages, in 2019 (A) and 2020 (B). 
The plants, which were about seven years old, were fertilized with bovine manure and bone meal and irrigated once a week. The flowering period occurred in January and fruits were picked in February, in both studied harvests (2019 and 2020).

The experiment was laid out in a completely randomized design with four replicates (each consisting of two fruits). The study was divided into two stages, according to the degree of fruit ripeness (ripe and commercially immature) at the time of harvest.

\section{Stage 1: Evaluations of fruits picked ripe}

In this stage, the fruits were picked when the skin was completely red, which occurred at 31 days (2019 harvest) and 35 days (2020 harvest) after the flower bud was produced (Figure 1). Once picked, the fruits were sent to the laboratory, and on the following day (one day after harvest), the respiratory activity (of that day only) of pitaya was evaluated according to a methodology adapted by Deliza, Castricini, Coneglian and Polidoro (2008). For this, the fruits were packed in 5,2 L plastic boxes (for six hours) with a beaker containing $10 \mathrm{~mL} 0.5 \mathrm{~N} \mathrm{NaOH}$ placed beside them. Results were expressed in $\mathrm{mg} \mathrm{CO} \mathrm{kg}^{-1} \mathrm{~h}^{-1}$. After the end of this evaluation, the same fruits were subjected to skin color assessments as well as the destructive assessments of flesh color, $\mathrm{pH}$, titratable acidity (TA), soluble solids (SS), SS/TA ratio, total betacyanins and ascorbic acid.

The instrumental color of the skin was determined using a Minolta colorimeter model Chroma meter CR 400. The apparatus adopted the $L^{*} C^{*} h{ }^{\circ}$ system (lightness, chroma and hue), in which lightness indicates the brightness of the color; chroma, its intensity; and hue, the saturation. Readings were taken at three different points on the fruits.

The $\mathrm{pH}$ was determined by potentiometry and titratable acidity was measured by titration with $0.1 \mathrm{M} \mathrm{NaOH}$, with results expressed in $\mathrm{g} 100 \mathrm{~g}^{-1}$ (citric acid). Soluble solids ( ${ }^{\circ}$ Brix) were determined using a digital refractometer (Instituto Adolfo Lutz [IAL], 2008). Total betacyanins (mg $100 \mathrm{~g}^{-1}$ ) in the flesh were determined following methodology described by Priatni and Pradita (2015) with modifications, whereby $5 \mathrm{~g}$ of sample and 40 $\mathrm{mL}$ of distilled water were placed in plastic pots with a lid (protected from light) and refrigerated for $24 \mathrm{~h}$. The extract was filtered through a polymer filter for coffee (Juliana filter, Injetemp) and read in a spectrophotometer at a $538 \mathrm{~nm}$ wavelength. For the determination of ascorbic

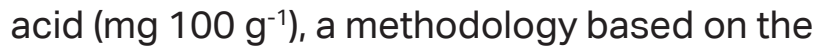
reduction of the 2,6-dichlorobenzeneindofenol indicator by ascorbic acid (Ministério da Agricultura, Pecuária e Abastecimento [MAPA], 2013) was adopted.

Step 2: Evaluations of fruits picked commercially immature

At this stage, the fruits were picked when the skin showed a greenish color (Figure 1), at 28 days (2019 harvest) and 30 days (2020 harvest) after flower bud production. After harvesting, the fruits were sent to thelaboratory, where they were kept stored for six days at an average temperature of $25^{\circ} \mathrm{C}$. During this period, respiratory activity was evaluated daily, following the same methodology described in step 1 for the ripe fruit.

In parallel with the daily assessment of respiratory activity, fresh-weight loss (fruits were weighed on a digital scale every day and 
the loss was calculated for each day in relation to the initial weight of the fruits; expressed in percentage terms) and instrumental color (only on the 1 st and 6 th days after harvest, due to technical problems with the machine, following the same methodology described in step 1 for the ripe fruit) were measured.

Because they are destructive, assessments of instrumental color, $\mathrm{pH}, \mathrm{TA}, \mathrm{SS}$, total betacyanins and ascorbic acid in the flesh of commercially immature pitaya took place on the 6th day (last evaluation day), following the same methodology in step 1 for the ripe fruits.

Data were initially subjected to the Shapiro-Wilk and Bartlett tests to check for error normality and homogeneity of variances. Fresh-weight loss data of fruits picked commercially immature (2019 and 2020 harvests) were subjected to analysis of variance, in which losses over the storage days were analyzed using regression. Because they did not meet the assumptions, the skin color data of fruits picked commercially immature (2020 harvest) were subjected to a nonparametric statistic, where the color change over the storage days was analyzed using Dunn's test.

Respiratory activity during ripening of the fruits picked commercially immature was analyzed by descriptive statistics.
Physical and chemical data of the flesh of commercially immature (referring to the last day of storage) and ripe fruits (one day after harvest) were compared by the $\mathrm{F}$ test to determine whether the fruits picked commercially immature would complete their ripening and would resemble the ripe produce. Similarly, the skin color of the commercially immature fruits in the 2019 harvest (which occurred only on the 1st and 6th days after harvest) was compared using the $F$ test.

All analyses were carried out at the $5 \%$ significance level.

\section{Results and Discussion}

Physical and chemical characterization of fruits picked ripe

One day after harvest, the fruits of both harvests (2019 and 2020) showed an intense dark-red skin color, according to the lightness, chroma and hue values (Table 1). In 2019, the fruit flesh exhibited a low-intensity dark and red hue and, in 2020, a more intense red flesh, as evidenced by the higher chroma value. 
Table 1

Physical and chemical traits of pitaya (Hylocereus polyrhizus) picked ripe (skin fully red), one day after harvest (2019 and 2020 harvests)

\begin{tabular}{|c|c|c|}
\hline Trait & 2019 harvest & 2020 harvest \\
\hline Skin lightness $\left(L^{*}\right)$ & $39.50 \pm 1.66$ & $41.70 \pm 0.93$ \\
\hline Skin chroma $\left(C^{*}\right)$ & $41.68 \pm 3.90$ & $44.46 \pm 3.02$ \\
\hline Skin hue $\left(h^{\circ}\right)$ & $26.83 \pm 3.15$ & $19.68 \pm 2.14$ \\
\hline Flesh lightness $\left(L^{*}\right)$ & $18.69 \pm 2.04$ & $20.02 \pm 0.65$ \\
\hline Flesh chroma $\left(C^{*}\right)$ & $16.70 \pm 2.91$ & $31.18 \pm 1.43$ \\
\hline Flesh hue $\left(h^{\circ}\right)$ & $5.21 \pm 0.49$ & $7.89 \pm 2.26$ \\
\hline $\mathrm{pH}$ & $4.49 \pm 0.13$ & $4.37 \pm 0.11$ \\
\hline Titratable acidity (g citric acid $100 \mathrm{~g}^{-1}$ ) & $0.34 \pm 0.06$ & $0.44 \pm 0.04$ \\
\hline Soluble solids ( $\left.{ }^{\circ} \mathrm{Brix}\right)$ & $10.98 \pm 0.75$ & $11.90 \pm 0.91$ \\
\hline SS/TA ratio & $33.52 \pm 5.75$ & $27.32 \pm 1.79$ \\
\hline Ascorbic acid (mg $\left.100 \mathrm{~g}^{-1}\right)$ & $11.59 \pm 2.30$ & $20.42 \pm 0.99$ \\
\hline Total betacyanins (mg $\left.100 \mathrm{~g}^{-1}\right)$ & $17.30 \pm 6.40$ & $19.63 \pm 9.38$ \\
\hline Respiratory activity $\left(\mathrm{mg} \mathrm{CO}_{2} \mathrm{~kg}^{-1} \mathrm{~h}^{-1}\right)$ & $21.51 \pm 2.10$ & $36.83 \pm 3.84$ \\
\hline
\end{tabular}

Data represent the average of four measurements \pm standard deviation.

One day after harvest, the $\mathrm{pH}$ of the flesh of pitaya was 4.49 (2019) and 4.37 (2020), and the respective TA was 0.34 and $0.44 \mathrm{~g}$ 100 g-1 (2019 and 2020 harvests). The SS contents in the respective produce were 10.98 and $11.90^{\circ}$ Brix. According to Vilas Boas et al. (2004), soluble solids are used as indicators of maturity and determine the quality of the fruit, playing an important role in its flavor. They consist mainly of soluble sugars, in addition to organic acids, vitamins, amino acids, pectins and soluble proteins, in smaller proportions (Fernandes, Vieites, Lima, Braga, \& Amaral, 2017).

As stated by Nascimento, Tomé, Oliveira, Müller and Carvalho (2003), a practical means of evaluating the taste of the fruits is by the ratio between soluble solids and titratable acidity (SS/TA), where high acidity values cause a reduction in the ratio, as observed in the fruits from the 2020 (SS/TA = 27.30) and 2019 (SS/TA = 33.52) harvests. Another noteworthy fact is that the higher the value of this ratio, the greater the sensation of sweetness to the human palate.

Fruits from the 2019 harvest were characterized as having a lower ascorbic acid

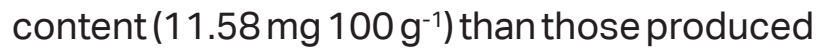
in 2020 (20.42 mg $\left.100 \mathrm{~g}^{-1}\right)$. These values exceed the minimum levels required by law (Instrução Normativa no 37 de 08 de Outubro de 2018) in the flesh of other traditional fruits such as mango (6.1 mg $\left.100 \mathrm{~g} \mathrm{~g}^{-1}\right)$, cajá (Spondias

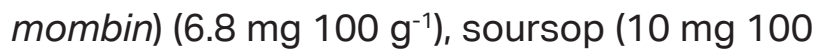
$\left.\mathrm{g}^{-1}\right)$ and kiwi (9 mg $\left.100 \mathrm{~g}^{-1}\right)$. The differences in the average values of ascorbic acid between the two harvests can be attributed to environmental factors, as observed by 
Pincemail, Kevers, Tabart, Defraigne and Dommes (2012) in a study with strawberries grown under the same conditions and picked at the same maturity stages and the same date, for two years. The authors attributed these differences possibly to climatic conditions. Ascorbic acid is a substance present in plants that has an antioxidant effect, i.e., it is able to sequester free radicals and neutralize their effects (Liziero, Karahasanovic, Spagnol, \& Isaac, 2017).

The average total betacyanin content present in the pitaya flesh was 17.30 in the 2019 harvest and $19.63 \mathrm{mg} 100 \mathrm{~g}^{-1}$ in the 2020 harvest. Betacyanins belong to the class of betalain pigments, present in cactus fruits (Stintzing, Schieber, \& Carle, 2003; Schiozer \& Barata, 2007), showing high antioxidant capacity (Vaillant, Perez, Davila, Dornier, \& Reynes, 2005). Due to the attractive red color it gives to foods, without changing their taste, the extract based on betacyanins, in the food industry, represents an alternative to replace synthetic dyes with natural ones (Ciriminna et al., 2018).

One day after harvest, the mean respiratory activity of the pitayas was 21.51 (2019 harvest) and $36.83 \mathrm{mg} \mathrm{CO}_{2} \mathrm{~kg}^{-1} \mathrm{~h}^{-1}(2020$ harvest), which is lower than those of soursop for six days after harvest: $298.82 \mathrm{mg} \mathrm{CO}_{2} \mathrm{~kg}^{-1}$ $\mathrm{h}^{-1}$ at the climatic peak (Lima, Alves, Filgueiras, \& Enéas-Filho, 2003).

The difference between fruit respiration values between the different harvests may have been due to the point of harvest, because although it is well-defined in pitaya, providing uniform qualitative traits, the fruits can be in different stages of maturation, which visually is not perceived but can lead to physiological differences. According to
Chitarra and Chitarra (2005), the physiological maturity of the same product or cultivar may differ at the time of harvest. The authors also stated that respiratory activity is influenced by the availability of substrates in the plant; for instance, organic acids and simple sugars (the average sugar content may vary according to climatic conditions), which may also explain the lower respiration in the fruits of the 2019 harvest (lower TA and SS values).

Fresh-weight loss, skin color and respiratory activity of fruits picked commercially immature

A significant effect was recorded for fresh-weight loss during storage $(p<0.05)$, which fitted an increasing linear model, with increases of $0.82 \%$ and $1.17 \%$ per storage day for the 2019 and 2020 harvests, respectively (Figure 2). According to Spotto and Gutierrez (2006), after the harvest, respiration promotes loss of water from plant tissues, compromising the quality of the plant product due to loss of fresh weight. Therefore, fresh-weight loss is a limiting factor for the preservation of the fruits, as it causes wrinkling of the skin and compromises the sale of the product even though the flesh is in good conditions for consumption (Duarte, Queiroz, Rocha, Costa, \& Abreu, 2017). However, despite being a physical phenomenon, this characteristic is linked to storage temperature, which in turn interferes with the fruit metabolism.

In the present study, in both harvests, at the end of storage, weight loss in the fruits was 5.18\% (2019 harvest) and 6.98\% (2020 harvest), which is above the acceptable fruit moisture content of $4.00 \%$ (Spoto \& Gutierrez, 2006). It is noteworthy that even with these values above the acceptable, the fruits did 
not show a compromised appearance, but the scales (bracts) were characteristic of dehydration, with a darkened and curled tip, which can lead to consumer rejection at the time of purchase. According to Mizrahi (2014), when fresh, pitayas are very attractive, but the wrinkling of their scales leaves the fruit with a poor appearance.
In 2019, due to technical problems with the machine, color readings on the skin were only taken at the times of one and six days after harvest (Table 2). There was a significant difference $(p<0.05)$ in the hue and color saturation (chroma) of the pitaya skin. One day after harvest, the fruits showed a skin with a light yellow-green hue, but after six days, the skin of these fruits acquired an intense red color due to the reduction of hue and increase in chroma.

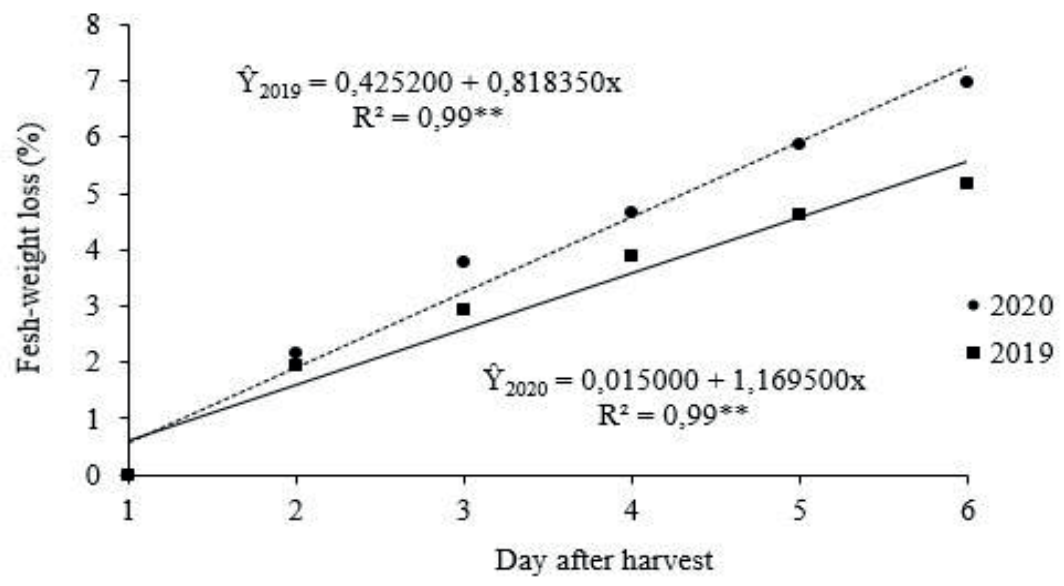

Figure 2. Fresh-weight loss (\%) in pitaya (Hylocereus polyrhizus) (2019 and 2020 harvests) picked at the commercially immature stage and stored at an average temperature of $25^{\circ} \mathrm{C}$.

\section{Table 2}

Lightness, chroma and hue of the skin of pitaya (Hylocereus polyrhizus) picked commercially immature, in 2019, at one and six days after harvest

\begin{tabular}{cccc|} 
& Lightness & Chroma & hue \\
\cline { 2 - 4 } Harvest & & 2019 harvest \\
\hline 1st day & $48.79 \mathrm{a}$ & $29.71 \mathrm{~b}$ & $106.39 \mathrm{a}$ \\
6th day & $40.91 \mathrm{~b}$ & $45.97 \mathrm{a}$ & $20.44 \mathrm{~b}$ \\
CV (\%) & 9.18 & 11.31 & 9.21
\end{tabular}

Means followed by the same letter do not differ by the $\mathrm{F}$ test at $5 \%$ significance. 
In the 2020 harvest, the color assessments took place during the ripening of the fruits. As shown in Table 3, one day after harvest, the skin of the fruits was lighter than on the 4th, 5th and 6th days. From the 4th day on, chroma was higher, indicating a greater color intensity, when compared with the 1st and 2 nd days. One day after harvest, hue differed from the 4th, 5th and 6th day. These results suggest that, one day after harvest, the skin color of the fruits was light green, which shifted to an intense and dark red from the 4th day. Therefore, there was degradation of chlorophyll and/or biosynthesis of carotenoids or betacyanins present in the skin, which is an indication although this phenomenon cannot be considered in isolation that the ripening process was taking place in the fruits that were picked still unripe. In this respect, Dantas, Silva, Dantas, Sousa and Schunemann (2016) concluded that the red-purple color characteristic of ripe Spondias sp., a fruit with a climacteric respiratory pattern, is achieved in the post-climacteric stage.

\section{Table 3}

Lightness, chroma and hue of skin of pitaya (Hylocereus polyrhizus) (2020 harvest) picked at commercially immature stages and stored at an average temperature of $25^{\circ} \mathrm{C}$

\begin{tabular}{cccc|}
\hline Days after harvest & Lightness & Chroma & hue \\
\hline 1 & $49.51 \mathrm{a}$ & $31.93 \mathrm{~b}$ & $117.38 \mathrm{a}$ \\
2 & $45.03 \mathrm{ab}$ & $29.05 \mathrm{~b}$ & $78.46 \mathrm{ab}$ \\
3 & $44.28 \mathrm{ab}$ & $41.43 \mathrm{ab}$ & $31.90 \mathrm{abc}$ \\
4 & $41.09 \mathrm{bc}$ & $46.79 \mathrm{a}$ & $25.42 \mathrm{bcd}$ \\
5 & $39.80 \mathrm{bc}$ & $46.05 \mathrm{a}$ & $24.19 \mathrm{~cd}$ \\
6 & $39.05 \mathrm{c}$ & $48.16 \mathrm{a}$ & $22.97 \mathrm{~d}$ \\
\hline
\end{tabular}

Means followed by the same lowercase letter do not differ by Dunn's nonparametric test at $5 \%$ significance.

As regards the daily respiratory behavior (Figure 3), depending on the days after harvest, in 2019, higher values were firstly observed (one day after harvest), which started to decline on the 2 nd day. This fact can be attributed to the average temperature of $27.99^{\circ} \mathrm{C}$ on the day of harvest (temperature recorded by the meteorological station of the National Institute of Meteorology - INMET, located in the same municipality of the study), which was superior to the storage conditions (average of $25^{\circ} \mathrm{C}$ ), and/or the stress caused by the collection and transport procedure to the laboratory. Despite the average temperature of $27.60^{\circ} \mathrm{C}$ on the harvest day, this behavior did not occur in the fruits picked in 2020. In a second moment, increased respiration was observed between the 2nd and 3rd days (in the fruits from both harvests), with a small increase in $\mathrm{CO}_{2}$ elimination, up to maximum respiration on the 3rd day and a subsequent decrease in $\mathrm{CO}_{2}$ until the end of the study, when there was also an increase in freshweight loss. Additionally, there was a change in color, which was more pronounced until the 3rd day (Table 3). 


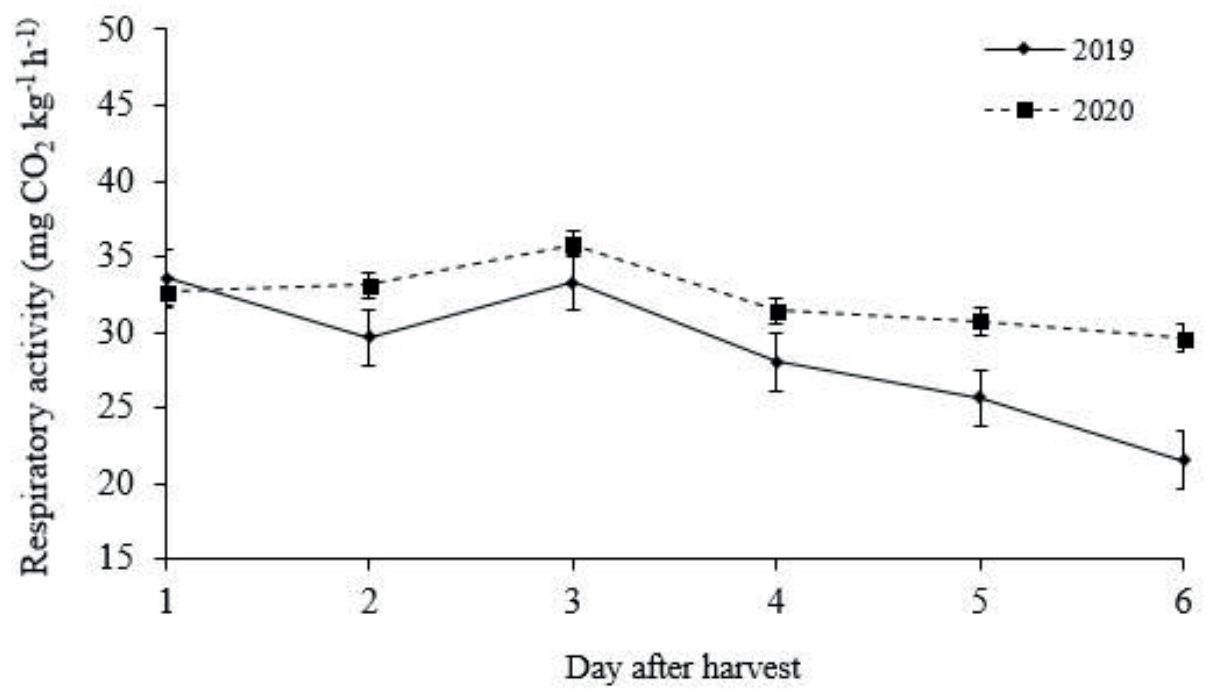

Figure 2. Respiratory activity of pitaya (Hylocereus polyrhizus) picked at a commercially immature stage, during six days of storage (2019 and 2020 harvests).

Although the literature states that pitayas are non-climacteric (Osuna et al., 2011; Jamaludin et al., 2011; Zee et al., 2004; Nerd et al., 1999), a small increase in respiration was observed in this study three days after both harvests (2019 and 2020). Similarly, Deaquiz et al. (2014) reported a climatic trend or intermediate climacteric behavior in yellow pitaya (Hylocereus megalanthus). There are variations in climatic behavior between species of the same genus. In addition, the variation in climacteric and non-climacteric behavior is observed even intraspecifically, as is the case of melon (Obando-Ulloa et al., 2008).

The average respiratory rate of pitayas picked in 2019 and 2020 was 28.64 and 32.32 mg CO$~_{2} \mathrm{~kg}^{-1} \mathrm{~h}^{-1}$, which reached a maximum of 33.57 and $35.85 \mathrm{mg} \mathrm{CO}_{2} \mathrm{~kg}^{-1} \mathrm{~h}^{-1}$, respectively. Higher or similar respiratory rates have been reported in other climacteric fruits such as peach and papaya (D. F. P. Silva, Silva, Matias, Ribeiro, \& Bruckner, 2013; Fonseca et al., 2006).

Physical and chemical traits of flesh from pitaya picked at different degrees of ripeness

In terms of flesh color (Table 4), there was a significant difference for the lightness and hue of the fruits from the 2020 harvest. This result indicates that despite the significant differences in hue, in that year, six days after harvest, the pitayas that were picked commercially immature also showed a flesh color tending to red, as it is situated in the quadrant that goes from $0^{\circ}$ to $90^{\circ}$ of the CIE $L^{*}$ $\mathrm{C}^{*} \mathrm{~h}^{\circ}$ system, with similar pigment saturation (chroma) in the flesh. 
Table 4

Lightness, chroma and hue in the flesh of pitaya (Hylocereus polyrhizus) picked ripe and six days after being picked commercially immature, in 2019 and 2020

\begin{tabular}{|c|c|c|c|}
\hline \multirow{2}{*}{ Fruit stage } & Lightness & Chroma & hue \\
\hline & \multicolumn{3}{|c|}{2019 harvest } \\
\hline Commercially immature** & $22.16 \mathrm{a}$ & 18.73 a & $4.21 \mathrm{a}$ \\
\hline Ripe* $^{*}$ & $18.69 \mathrm{a}$ & $16.70 \mathrm{a}$ & $5.21 \mathrm{a}$ \\
\hline \multirow[t]{2}{*}{ CV (\%) } & 3.32 & 13.57 & 60.44 \\
\hline & & \multicolumn{2}{|c|}{2020 harvest } \\
\hline Commercially immature** & $21.80 a$ & $29.11 \mathrm{a}$ & $15.26 \mathrm{a}$ \\
\hline Ripe* & $20.02 b$ & $31.18 \mathrm{a}$ & $7.89 \mathrm{~b}$ \\
\hline CV (\%) & 3.46 & 5.34 & 14.05 \\
\hline
\end{tabular}

Means followed by the same letter in the columns do not differ, in each harvest, by the $\mathrm{F}$ test at $5 \%$ significance.

** Evaluations carried out six days after harvest; * Values shown in Table 1.

As shown in Table 5, in the 2019 harvest, only the SS/TA ratios of the fruits picked at different degrees of ripeness were significantly different, with the highest ratio observed in the fruits picked ripe, indicating more advanced maturation. However, although this trait is considered one of the most practical ways to evaluate the taste of fruits (Chitarra \& Chitarra, 2005; Nascimento et al., 2003), there was no difference in the SS and TA contents regardless of the degree of ripeness at which the fruits were picked.

\section{Table 5}

Chemical characteristics such as $\mathrm{pH}$, titratable acidity (TA), soluble solids (SS), SS/TA ratio, total betacyanins (mg $100 \mathrm{~g}$ ) and ascorbic acid (mg $100 \mathrm{~g}$ ) in the flesh of pitaya (Hylocereus polyrhizus) picked at different degrees of ripeness and evaluated at different times after harvest (2019 and 2020 harvests)

\begin{tabular}{|c|c|c|c|c|c|c|}
\hline \multirow{2}{*}{ Fruit stage } & $\mathrm{pH}$ & AT & SS & SS/TA & Betacyanins & Ascorbic acid \\
\hline & \multicolumn{6}{|c|}{2019 harvest } \\
\hline Commercially immature** & $4.59 a$ & $0.40 a$ & $8.88 \mathrm{a}$ & $22.59 \mathrm{~b}$ & $17.60 \mathrm{a}$ & $14.56 \mathrm{a}$ \\
\hline Ripe* & $4.49 a$ & $0.34 \mathrm{a}$ & $10.98 a$ & $33.52 a$ & $17.30 \mathrm{a}$ & $11.59 \mathrm{a}$ \\
\hline \multirow[t]{2}{*}{ CV (\%) } & 3.14 & 17.89 & 10.57 & 19.29 & 42.87 & 25.37 \\
\hline & \multicolumn{6}{|c|}{2020 harvest } \\
\hline Commercially immature** & $4.93 a$ & $0.30 \mathrm{~b}$ & $9.72 b$ & $34.07 \mathrm{a}$ & $13.90 \mathrm{a}$ & $21.95 \mathrm{a}$ \\
\hline Ripe* & $4.36 \mathrm{~b}$ & $0.43 a$ & $11.90 \mathrm{a}$ & $27.32 \mathrm{a}$ & 19.63 a & $20.42 \mathrm{a}$ \\
\hline CV (\%) & 3.11 & 19.68 & 6.26 & 22.29 & 41.17 & 17.04 \\
\hline
\end{tabular}

Means in the columns followed by the same letter do not differ, in each harvest, by the $\mathrm{F}$ test at $5 \%$ significance.

* Evaluations carried out six days after harvest; ** Values shown in Table 1. 
In the 2020 harvest, the $\mathrm{pH}$, TA and SS content of the pitayas changed according to the degree of ripeness at the time of harvest, with the commercially immature fruits showing less acidity and SS at six days after harvest. Besides intrinsic characteristics of the fruits, this finding may be related to the conditions in which the fruits were produced. Hornick (1992) reported that the soil, the climate, the crop itself and the variety, management practices and post-harvest handling and storage are factors that influence the nutritional quality of fruits, which was confirmed in other studies with pitayas (Duarte et al., 2017; A. C. C. Silva, Martins, \& Cavallari, 2011). Unlike in the 2019 produce, the SS/TA ratio in the fruits from the 2020 harvest did not differ between the ripening degrees. This is an indication that this trait can be influenced by the environment and climatic conditions of the fruit growth and development period as well as the day of harvest.

The total betacyanin content did not differ between the harvests, in the fruits picked at different degrees of ripeness. Nerd et al. (1999) reported that in pitayas of the species $\mathrm{H}$. polyrhizus, the pigmentation responsible for the red-violet color of the flesh increased in parallel with the development of skin color. This fact was observed in the commercially immature fruits in current the study, in which there was a change in skin color but no changes in total betacyanin content. Changes in skin and flesh color are usually due to the degradation of the chlorophyll present in the tissues and consequent visualization of the pigments already present, which explains the non-variation of the betacyanin content along the ripening time post-harvest. Alternatively, in some cases, color changes may stem from the biosynthesis of these pigments during ripening, which explains the increase in the content of these pigments as the fruit ripens.

The ascorbic acid (vitamin C) content of the fruits from both harvests did not differ when they were picked at different stages of ripening. According to Lee and Kader (2000), maturity is one of the major factors determining the quality of the composition of ascorbic acid in fruits. Other factors such as long-term storage, high temperatures, low relative humidity, physical damage and cold injuries promote loss of this vitamin, which is most sensitive after harvest (Koblitz, 2014). Centurión Yah, Solís Pereira, Saucedo Veloz, Báez Sañudo and Sauri Duch (2008) evaluated the ascorbic acid content of $\mathrm{H}$. undatus pitaya and observed a higher value in immature fruits, 20 days after floral opening, which decreased 31 days after floral opening.

\section{Conclusion}

Pitayas picked commercially immature and in two different harvests showed increased respiratory activity after harvest, with a change in skin color during storage.

The post-harvest alterations of commercially immature pitaya, six days after harvest, in the 2019 harvest, are similar to those of the fruits that ripened on the plant.

In the 2020 harvest, six days after harvest, pitayas picked fully ripe have SS/TA ratio, betacyanins and ascorbic acid content similar to those of fruits picked commercially immature. 


\section{Acknowledgments}

Thanks are extended to the National Council for Scientific and Technological Development (CNPq), for the financial support for conducting the research (Finance Code 420469/2016-8); to the Minas Gerais Research Support Foundation (FAPEMIG) for granting the State Public Researcher Incentive Fellowship - BIPDT; and to the Coordination for the Improvement of Higher Education Personnel Brazil (CAPES) - (Code 001).

\section{References}

Centurión Yah, A. R., Solís Pereira, S., Saucedo Veloz, C., Báez Sañudo, R., \& Sauri Duch, E. (2008). Cambios físicos, químicos y sensoriales en frutos de pitahaya (Hylocereus undatus) durante su desarrollo. Revista Fitotecnia Mexicana, 31(1), 1-5. Recuperado de https://www. redalyc.org/pdf/610/61 031101.pdf

Chitarra, M. I. F., \& Chitarra, A. B. (2005). Póscolheita de frutas e hortaliças - fisiologia e manuseio. Lavras: Editora UFLA.

Ciriminna, R., Fidalgo, A., Danzì, C., Timpanaro, G., Ilharco, L. M., \& Pagliaro, M. (2018). Betanin: a bioeconomy insight into a valued betacyanin. ACS Sustainable Chemistry \& Engineering, 6(3), 2860-2865. doi: 10.1021 /acssuschemeng.7b04163

Dantas, A. L., Silva, S. M., Dantas, R. L., Sousa, A. S. B., \& Schunemann, A. P. P. (2016). Desenvolvimento, fisiologia da maturação e indicadores do ponto de colheita de frutos da umbugueleira (Spondias sp.). Revista Brasileira de Fruticultura, 38(1), 33-42. doi: 10.1590/0100-2945-271/14
Deaquiz, Y. A., Álvarez-Herrera, J., \& Fischer, G. (2014). Ethylene and 1-MCP affect the postharvest behavior of yellow pitahaya fruits (Selenicereus megalanthus Haw.). Agronomía Colombiana, 32(1), 44-51. doi: 10.15446/agron.colomb.v32n1.41950

Deliza, R., Castricini, A., Coneglian, R. C. C., \& Polidoro, J. C. (2008). Determinação da taxa respiratória de mamão 'Golden'. (Comunicado Técnico, 132). Rio de Janeiro, RJ: EMBRAPA.

Donadio, L. C. (2009). Pitaya. Revista Brasileira de Fruticultura, 31(3), 637-929. doi: 10.1590/S0100-294 52009000300001

Duarte, L. E. B., Rivera, J. A. C., \& Cuenca, C. E. N. (2005). Catalasa, peroxidasa y polifenoloxidasa en pitaya amarilla (Acanthocereus pitajaya): maduración y senescencia. Acta Biológica Colombiana, 10(2), 49-59. Retrieved from https:// revistas.unal.edu.co/index.php/actabiol/ article/download/27131/27404

Duarte, M. H., Queiroz, E. R., Rocha, D. A., Costa, A. C., \& Abreu, C. M. P. (2017). Qualidade de pitaia (Hylocereus undatus) submetida à adubação orgânica e armazenada sob refrigeração. Brazilian Journal of Food Technology, 20, e2015115. doi: 10.1590/1981-6723.11515

Fernandes, L. M. S., Vieites, R. L., Lima, G. P. P., Braga, C. L, \& Amaral, J. L. (2017). Caracterização do fruto de pitaia orgânica. Biodiversidade, 16(1), 167-179. Recuperado de http://www.periodicos cientificos.ufmt.br/ojs/index.php/ biodiversidade/article/view/4981

Fonseca, M. J. O., Leal, N. R., Cenci, S. A., Cecon, P. R., Bressan-Smith, R. E., \& Soares, A. G. (2006). Emissão de etileno 
e de CO2 em mamão 'Sunrise Solo' e 'Golden'. Revista Brasileira de Fruticultura, 28(2), 322-324. doi: 10.1590/S010029452006000200038

Gómez-Galindo, F., Herppich, W., Gekas, V., \& Sjöholm, I. (2004). Factors affecting quality and postharvest properties of vegetables: Integration of water relations and metabolism. Critical Reviews in Food Science and Nutrition, 44(3), 139-154. doi: 10.1080/10408690490424649

Hornick, S. B. (1992). Factors affecting the nutritional quality of crops. American Journal of Alternative Agriculture, 7(1-2), 63-68.doi:10.1017/S0889189300004471

Instituto Adolfo Lutz (2008). Métodos físicoquímicos para análise de alimentos. Recuperado de http:/ /www.ial.sp.gov.br/ resources/editorinplace/ial/2016_3_19/ analisedealimentosial_2008.pdf?attach =true

Instrução Normativa $\mathrm{n}^{\circ} 37$, de 08 de outubro de 2018. Parâmetros analíticos de suco e de polpa de frutas. Recuperado de https:// www.in.gov.br/materia/-lasset_publisher/ Kujrw0TZC2Mb/content/id/44304943/ do1-2018-10-08-instrucao-normativa-n37-de-1-de-outubro-de-2018-44304612

Jamaludin, N. A., Ding, P., \& Hamid, A. A. (2011). Physico-chemical and structural changes of red fleshed dragon fruit (Hylocereus polyrhizus) during fruit development. Journal of the Science of Food and Agriculture, 91(2), 278-285. doi: 10.1002/ jsfa.4182

Koblitz, M. G. B. (2014). Matérias-primas alimentícias: composição e controle de qualidade (Reimp.). Rio de Janeiro: Guanabara Koogan.
Lee, S. K., \& Kader, A. A. (2000). Preharvest and postharvest factors influencing vitamin $C$ content of horticultural crops. Postharvest Biology and Technology, 20(3), 207-220. doi: 10.1016/S0925-5214(00) 00133-2

Lima, M. A. C., Alves, R. B., Filgueiras, H. A. C., \& Enéas-Filho, J. (2003). Comportamento respiratório e qualidade pós-colheita de graviola (Annona muricata L.) 'Morada' sob temperatura ambiente. Revista Brasileira de Fruticultura, 25(1), 49-52. doi: 10.1590/ S0100-29452003000100015

Liziero, D. F. P., Karahasanovic, A., Spagnol, C. M., \& Isaac, V. L. B. (2017). Metodologia simplificada para doseamento de ácido ascórbico em extratos vegetais. Revista Brasileira Multidisciplinar, 20(2), 80-87. Recuperado de http://revistarebram.com/ index.php/revistauniara/article/view/520/ pdf_1

Ministério da Agricultura, Pecuária e Abastecimento (2013). Análises físicoquímicas de bebidas e vinagres - MET BEB/006/001. Método para determinação de ácido ascórbico. Lanagro, SP.

Mizrahi, Y. (2014). Vine-cacti pitayas: the new crops of the world. Revista Brasileira de Fruticultura, 36(1), 124-138. doi: 10.1590/0100-2945-452/13

Mizrahi, Y., \& Nerd, A. (1999). Climbing and columnar cacti: new arid land fruit crops. In J. Janick. (Ed.), Perspective in new crops and new crops uses (pp. 358366). Alexandria: ASHS. Recuperado de https:// hort.purdue.edu/newcrop/ proceedings 1999/pdf/mizrahi.pdf

Nascimento, W. M. O., Tomé, A. T., Oliveira, M. S. P., Müller, C. H., \& Carvalho, J. E. U. (2003). Seleção de progênies de 
maracujazeiro-amarelo (Passiflora edulis f. flavicarpa) quanto à qualidade de frutos. Revista Brasileira de Fruticultura, 25(1), 186-188. doi: 10.1590/S0100-29 452003000100052

Nerd, A., Gutman, F., \& Mizrahi, Y. (1999). Ripening and postharvest behaviour of fruits of two Hylocereus species (Cactaceae). Postharvest Biology and Technology, 17(1), 39-45. doi: 10.1016/ S0925-5214(99) 00035-6

Obando-Ulloa, J. M., Moreno, E., García-Mas, J., Nicolai, B., Lammertyn, J., Monforte, A. J., \& Fernández-Trujillo, J. P. (2008). Climacteric or non-climacteric behavior in melon fruit: 1. Aroma volatiles. Postharvest Biology and Technology, 49(1), 27-37. doi: 10.1016/j.postharvbio.2007.11.004

Osuna, E., Ibarra, Z., Muy, R., Valdez, T., Villarreal, R., \& Hernández, V. (2011). Postharvest quality of pitahaya (Hylocereus undatus Haw.) fruits harvested in three maturity stages. Revista Fitotecnia Mexicana, 34(1), 63-72. Recuperado de https://www.cabdirect.org/cabdirect/ abstract/20113164032

Pincemail, J., Kevers, C., Tabart, J., Defraigne, J. O., \& Dommes, J. (2012). Cultivars, culture, conditions, and harvest time influence phenolic and ascorbic acid aontents and antioxidant capacity of strawberry (Fragaria $x$ ananassa). Journal of Food Science, 77(2), C205-C210. doi: 10.1111/ j.1750-3841.2011.02 539.x

Priatni, S., \& Pradita, A. (2015). Stability study of betacyanin extract from red dragon fruit (Hylocereus polyrhizus) peels. Precedia Chemistry, 16, 438-444. doi: 10.1016/j. proche.2015.12.076
Schiozer, A. L., \& Barata, L. E. S. (2007). Estabilidade de corantes e pigmentos de origem vegetal. Revista Fitos, 3(2), 6-24. Recuperado de https://www.arca.fiocruz. br/handle/icict/19149

Silva, A. C. C., Martins, A. B. G., \& Cavallari, L. L. (2011). Qualidade de frutos de pitaya em função da época de polinização, da fonte de pólen e da coloração da cobertura. Revista Brasileira de Fruticultura, 33(4), 1162-1168. doi: 10.1590/S0100-294520 11000400014

Silva, D. F. P., Silva, J. O. D. C. E., Matias, R. G. P., Ribeiro, M. R., \& Bruckner, C. H. (2013). Curva de crescimento e padrão respiratório de frutos de genótipos de pessegueiro em região de clima subtropical. Revista Brasileira de Fruticultura, 35(2), 642-649. doi: 10.1590/ S0100-29452013000200037

Spoto, M. H. F., \& Gutierrez, A. S. D. (2006). Qualidade pós-colheita de frutas e hortaliças. Em fundamentos de ciência e tecnologia de alimentos (pp. 403-450). São Paulo: Manole.

Stintzing, F. C., Schieber, A., \& Carle, R. (2003). Evaluation of colour properties and chemical quality parameters of cactus juices. European food Research \& Technology, 216, 303-311. doi: 10.1007/ s00217-002-0657-0

Taiz, L., Zeiger, E., Møller, I. M., \& Murphy, A. (2015). Plant physiology and development. Sunderland, U.S.A.: Sinauer Associates. Inc.

Tel-Zur, N., Mizrahi, Y., Cisneros, A., Mouyal, J., Schneider, B., \& Doyle, J. J. (2011). Phenotypic and genomic characterization of vine cactus collection (Cactaceae). 
Genetic Resources and Crop Evolution, 58(7), 1075-1085. doi: 10.1007/s10722010-9643-8

Vaillant, F., Perez, A., Davila, I., Dornier, M., \& Reynes, M. (2005). Colorant and antioxidant properties of red-purple pitahaya (Hylocereus sp.). Fruits, 60(1), 3-12. doi: 10.1051/fruits:2005007

Vilas Boas, B. M., Nunes, E. E., Fiorini, F. V. A., Lima, L. C. O., Vilas Boas, E. V. B., \& Coelho, A. H. R. (2004). Avaliação da qualidade de mangas 'Tommy Atkins' minimamente processadas. Revista Brasileira de Fruticultura, 26(3), 540-543. doi: 10.1590/ S0100-29452004000300040
Weiss, I., Mizrahi, Y., \& Raveh, E. (2010). Effect of elevated $\mathrm{CO} 2$ on vegetative and reproductive growth characteristics of the CAM plants Hylocereus undatus and Selenicereus megalanthus. Scientia Horticulturae, 123(4), 531-536. doi: 10.1016/j.scienta.2009.11.002

Zee, F., Yen, C. R., \& Nishina, M. (2004). Pitaya (dragon fruit, strawberry pear). Fruits and Nuts, (9), 1-3. Retrieved from https:// scholarspace.manoa.hawaii.edu/ bitstream/10125/2403/FN-9.pdf 